\title{
A Streamflow Threshold Determination Method for Hydrologic Model Calibration and Verification
}

\author{
N.T.S. Wijesekera
}

\begin{abstract}
Identification of the type and characteristics of streamflow in a watershed is the key to the development of most appropriate water infrastructure. Though these features are watershed specific, the current practice is to capture the details using generalized thresholds. Considering the importance of optimal resource use, present-day water engineers must resort to methodologies that enable the determination of streamflow thresholds of a watershed by making use of watershed signatures. In the present work, a watershed hydrology-based method to capture the high, intermediate and low streamflow thresholds is presented with a demonstration using data of the Kalu Ganga basin of Sri Lanka. The acceptability of thresholds is established by application and supported with literature quoted practice. Repeatability of the method is successfully confirmed by application at Gin Ganga basin of Sri Lanka for two different data lengths and two temporal resolutions. Described method conjunctively evaluates the consistent streamflow segments and average slope of the flow duration curve to determine the thresholds which are watershed signatures for a particular temporal resolution. This dependence on temporal resolution while highlighting the importance of using appropriate thresholds for meaningful hydrologic model evaluations, cautions the use of traditional methods based on generalized thresholds. Proposed method is a versatile tool for model development with specific objectives such as water allocation, regulation, flood management, water extraction or environmental flow maintenance. Identification of thresholds using this method builds the confidence of practicing engineers when using design safety factors for streamflow.
\end{abstract}

Keywords: Sri Lanka, Streamflow modelling, Flow duration curve, Calibration, Verification

\section{Introduction}

Predicting watershed streamflow is an immense challenge faced by the present-day hydrologic modellers. Hydrologic models for streamflow estimation serve two main purposes. One is the reproduction of watershed response for practical water management activities such as drinking water supply, flood and drought management, irrigated agriculture and environmental sustenance. The other is for the enhanced scientific understanding of hydrological processes. Even after several decades of practice, mathematical models have shown only limited success in the reproduction of hydrologic behaviour of a watershed [1], [2]. Optimum parameters of a hydrologic model depend on the type of selected model [3] and objective function [4]. Accurate modelling of the entire streamflow spectrum which ranges from low environmental flows to high floods faces two constraints.

One constraint is the limited understanding of watershed hydrology. There are many conceptualization options to model watersheds
[5]-[7]. There are also sophisticated data dominating models developed with a combination of hydro and hydrologic laws that follow known physics [8], [9]. Even though there are many options, present-day watershed managers strive to find a watershed model for the purpose of expressing the whole spectrum of runoff regimes [10]. There is no option in the models to optimise time variant parameters based on the dominant processes. Some experts, while pointing to the deficiencies in the hydrological representations, argue that prevailing hydrologic laws require a revisit.

The other constraint is the difficulty when selecting an appropriate objective function for model calibration and verification [11]. There

\footnotetext{
Eng. (Prof.) N.T.S.Wijesekera, C. Eng., FIE(Sri Lanka), MICE (UK), B.Sc. Eng. (SL), PG Dip Hyd. Structures (Moratuwa), M. Eng. (Tokyo), D. Eng. (Tokyo). Senior Professor of Civil Engineering, Department of Civil Engineering, University of Moratuwa, Sri Lanka. Email:sohan@civil.mrt.ac.lk

(iD https://orcid.org/0000-0003-09644331
} 
are recent researches which comparatively evaluate the strengths of various single objective functions while there are others which focus on the identification of better and efficient multi objective functions. There is also the continued concern regarding the restricted abilities of hydrologic models to provide a good forecasting performance partly because of the difficulty in carrying out a meaningful evaluation of the model components and parameter fields [11], [12]. At the same time, most objective functions and models are capable of satisfactorily reproducing a specific part of the streamflow spectrum [13]-[15].

The question that has to be answered is whether watershed modelling difficulties are due to the aforesaid recognized ignorance or due to total ignorance [16] associated with watershed hydrology, or is it due to inadequacies when incorporating an objective function, or is it due to both. Present status of research indicates that satisfactory clarifications for the above question to eventually serve as modelling guidelines would require more time to mature. Until then, the problem or the real challenge in front of water engineers and managers is to carryout rational decision-making for sustainable water resources planning and infrastructure development amidst the said issues of models and modelling. A prudent solution to overcome these issues is to develop and calibrate hydrologic models to serve either a specific water management objective or a combination of objectives.

A water manager's service delivery objective is always linked to a specific streamflow category that has to be managed rationally [11], [17]. Therefore, a clear knowledge on the magnitude and boundaries of a streamflow category is very important for an educated water management practice [4], [18]-[20]. Identification of streamflow categories as high, intermediate and low is conceptually coherent among water managers and the research community. Flood and disaster managers give attention to the high-flows [21]. The magnitude and frequency of high and lowflows which regulate numerous ecological processes demonstrate a much higher importance in a rapidly changing climate [22], [23]. Among other environmental security concerns, low-flow depth is important for the migration period of the fish species while highflows also need adequate consideration when catering to fish migration [24]. These streamflow thresholds are watershed specific because the characteristics of a streamflow hydrograph are watershed dependent [25]. Such thresholds also vary with the selected time resolution because of aggregation and truncation effects.

Knowledge on the streamflow thresholds is important when making decisions with respect to planning, design and management, but it becomes critical when mathematical models are calibrated and verified for the purpose of generating streamflow to evaluate critical scenario [26]-[28]. Hence it is prudent to determine "watershed hydrology driven streamflow thresholds" to properly plan and perform the tasks of water resources management [13], [19].

The prevailing practices of flow threshold identification are mostly based on generally accepted universal exceedance levels. These numbers do not consider the unique behaviour of a particular watershed that is reflected in the shape of its Flow Duration Curve (FDC). In the present global setting where water has become extremely precious, each watershed must be carefully assessed and rationally managed to fulfil the needs of all water users. Water managers interested in activities such as floods must evaluate streamflow on a daily time scale while water resources planners who target activities such as irrigation need to use monthly temporal resolution. Streamflow behaviour depends on watershed characteristics and the selected time scales.

Therefore, responsible water managers and engineers need to move away from generalizations and get closer to watershed specific assessments demonstrating that management decisions are nearer to the realities of their watershed. This can be achieved only with watershed models that have been tested for their performance with respect to a desired streamflow category. Hence it is of utmost importance to identify streamflow exceedance thresholds based on watershed characteristics.

Accordingly, the present work developed a method to capture watershed specific exceedance thresholds for classification of streamflow at a desired temporal resolution. The developed method is demonstrated by evaluating a watershed in the Kalu Ganga basin of tropical Sri Lanka (Figure 1) by considering two temporal data resolutions. 
Then repeatability was verified by evaluating a watershed in the Gin Ganga basin of Sri Lanka (Figure 2), utilizing two temporal resolutions and two data periods. Comparison of identified streamflow thresholds and observed streamflow also demonstrated the acceptability of computed values.

\section{Present Setting}

Many research contributions such as attempts to determine environmental flow thresholds highlight the importance of a threshold identification method based on watershed signature [29]. Shape of FDC which is unique to a watershed had been used by several researchers to qualitatively capture streamflow thresholds [12], [30]-[32]. Wagener et al. [33] recognized three streamflow components with respect to a rainfall driven watershed status. Huang and Loucks [34] identified the high, intermediate and low streamflow classification as probability-based thresholds for water resources management under uncertainty. Recognizing a range of percentiles corresponding to exceedance probabilities has been a widely used method for the determination of streamflow thresholds [4], [18]-[20].

Though the above cited works indicate many options to determine thresholds, statistically determined flow percentiles appear as the popular choice for planning and design [35]. Laaha and Blöschl [36] recommend a low flow determination procedure for Austria favored $Q_{95}$ because of wide European usage and the relevance to water resources management. Gustard et al. [37] also reported the use of $Q_{95}$ as the low flow threshold because of its wide usage in the water industry. While considering that high and low-flow zones are centered at $5^{\text {th }}$ and $95^{\text {th }}$ percentiles respectively, Environmental Protection Agency [38] states that other schemes also can be used depending on local hydrology. Smakhtin et al. [29] mentions that streamflow within the range of $70-99 \%$ time of exceedance is most widely used as design low-flows, and Sugiyama et al. [39] stated that a widely practiced low-flow index had considered streamflow at $97 \%$ time of exceedance as the threshold. High streamflow is often considered as the flow which is available $5-10 \%$ of the time. USGS report 2008-5126 has considered $5^{\text {th }}$ and $10^{\text {th }}$ percent exceedances as high-flow and the 95th percent exceedance as low-flow [40]. With respect to water extractions, Geological Survey had adopted the flow available at $50 \%$ of the time $\left(Q_{50}\right)$ and the flow available at $90 \%$ of the time $\left(Q_{90}\right)$ as standards of flow for waterpower statistics [41]. Li et al. [42] used the flow available for $5 \%$ of the time as high flow for their work on climate variability and human activities. Sung and Chung [43] in their work had used $Q_{70}$ as the low-flow threshold for drought evaluation. Kjeldsen et al. [44] making proposals for a truncation level between 50\% and $90 \%$ as the low-flow threshold had fixed the level at $75^{\text {th }}$ percentile of the FDC. Work on the design streamflow for fish migration had considered $95 \%$ exceedance flow as the lower threshold, and a high-flow design discharge that did not exceed more than $10 \%$ of the time during the months of migration [24]. An approach recognizing five streamflow zones has been used in guideline development for maximum daily loads. In this, the EPA [38] had recognized five zones with one representing high flows $(0-10 \%)$, another for moist conditions $(10-40 \%)$, one covering midrange flows (40-60\%), another for dry conditions (60-90\%), and one representing lowflows (90-100\%). In literature, there are several threshold identification methods used for various water management approaches. They are, 1) Visualizing critical regions and identifying truncation levels for droughts and environmental flow [44], [45], 2) Subjective partitioning of the FDC for segments [12], 3) Judgmentally utilizing the shape and slope of FDC [30]-[32], [46], 4) Accepting a level of exceedance. Though all these methods indicate a close similarity, they do not demonstrate or justify the selections as suitable values for a concerned watershed.

\section{Methodology}

\subsection{FDC as the Tool}

The most appropriate tool for the determination of streamflow thresholds is the Flow Duration Curve (FDC). FDC, which is a cumulative frequency curve that shows the percent of time specified discharges were equaled or exceeded during a given period, reflects the natural behaviour of streamflow categories [41]. The use of this aspect is well contemplated in many publications [40], [47][50]. There are applications related to water power engineering, water supply, locating of industrial plants, pollution studies, climate change impacts and human activities etc., that have utilized flow thresholds linked to flow duration curves [41], [42]. 


\subsection{FDC Type}

Flow duration curves which can either be a plot of streamflow versus the time of exceedance or streamflow versus the exceedance probability, portrait the characteristics of a watershed with respect to its streamflow [41], [44], [48]. Research documenting the advantages of FDC opt to use the exceedance probability plots [39], [51], [52]. FDCs also differ with the temporal resolution of data. Use of daily and monthly data is quite common. Even though monthly or annual FDC are valuable for water resources evaluations [45], they do not permit evaluation of flow variability in streams because there are significant differences in the behaviour of daily and monthly FDC types [18], [41], [53]-[55]. Therefore, the selection of temporal resolution depends on the desired objective of an application. FDC used for hydrological evaluations also vary with the selected data duration. A "Period of Record" or "Steady State" FDC represents the likelihood of streamflow over a long planning horizon, annual FDC reflects the interannual flow variations, while the "Median Annual FDC (MA FDC)" is minimally affected by the abnormally wet or dry periods [53]. Accordingly, the Period of Record (PoR) FDC which has a higher potential to capture the long-term streamflow responses, together with the probability of exceedance option, were utilized in the present work for the evaluations at monthly and daily temporal resolutions.

\subsection{Conceptualization}

The streamflow threshold identification method developed in the present work is founded on the core characteristics of FDCs. They are, 1) Lower probability of exceedance (PoE) region of FDC is associated with high streamflow values which show a rapid variation of magnitude, 2) Higher PoE region of FDC is associated with the lowest streamflow values which also reflect a rapid variation of magnitude, 3) The PoE axis of FDC reflects a relatively consistent intermediate streamflow region with a gradual variation of magnitude, 4) In high, intermediate and low streamflow regions of FDC, the order of magnitude of average streamflow has a noticeable difference, 5) Order of magnitude of streamflow suggests the possibility of partitioning the FDC to display segments with consistent streamflow magnitudes, 6) Change of gradient between Consistent Streamflow Segments (CSS) signify the three main classes of watershed streamflow.
In this work, the order of magnitude of streamflow rate is used to capture the change of characteristics in a given stream. Initially, an Order of Magnitude FDC (OM FDC) is plotted to capture the slope change points belonging to segments having the same order of magnitude. Semi logarithmic FDC enables an easy comparison of gradient change in both high and low flow regions. Hence, the gradient of streamflow change is computed using the logarithms of observed streamflow. Slope between change points when plotted against the PoE, visibly differentiates three major streamflow categories. Rapid decrease of slope in the lower PoE region demarcates the high flows. The near uniform slope in the mid PoE region belongs to the intermediate flows. In the higher PoE region the slope values rapidly increase to show the low flow region. The slope change points corresponding to the transition from one flow type to the other can be distinctly recognized. Projection of each slope change point to the FDC enables the identification of two streamflow values associated with the slope change point. The order of magnitude streamflow at the high streamflow end of the FDC is the high streamflow threshold while the same at the low streamflow end of FDC is the low streamflow threshold. Once these streamflow thresholds are captured then they enable the identification of corresponding PoE values.

\subsection{Application}

Watersheds of Gin Ganga at Tawalama and Kalu Ganga at Ellagawa are situated in the wet zone of Sri Lanka. They drain towards the west coast and receive rainfall from both South-West and North-East monsoons. Daily streamflow data for 8 water-years (2006/20072013/2014) in Kalu Ganga watershed at gauging station Ellagawa $\left(1372 \mathrm{~km}^{2}\right)$ were used to demonstrate the identification of streamflow thresholds in the monthly and daily temporal scales. The water year for Sri Lanka commences from the month of October [56]. Average annual streamflow of Kalu Ganga over the study period is 1517 $\mathrm{mm} /$ year.

In the absence of country specific daily streamflow studies such as in the work of Blum et al. [57], the Probability of Exceedance (PoE) values were computed as recommended by Chow et al. [58]. In the present computations, it was assumed that the observations could be categorized as normally distributed, unbiased, distributed according to 
Extreme Value Type 1 and choosing a parameter value of $3 / 8$ for an unbiased plotting position [59]. At first, observed streamflow values were rounded to reflect the time periods having streamflow of similar order of magnitude (equation 1).

$$
Q O M_{i}=\operatorname{MROUND}\left[Q_{i}, 10^{K}\right]
$$

In equation $1, Q O M_{i}$ is the rounded observed streamflow in $\mathrm{mm}$ per unit area per unit time, $Q_{i}$ is the observed streamflow in mm per unit area per unit time, MROUND[ ] is a function which denotes rounding off the observed streamflow to the nearest multiple of $10^{\mathrm{K}}$ and $\mathrm{K}$ is the integer value of the $\log _{10}\left(Q_{i}\right)$. In this, $i$ varies from 1 to $m$ where $m$ is the number of streamflow data in the PoE FDC. This equation easily captures the order of magnitude of both integers and fractions to multiples of 10 .

Stepped duration curve developed with $Q O M$ values highlights the segments with similar streamflow magnitudes and PoE values corresponding to the change of streamflow magnitude. Midpoint PoE of each CSS (equation 2) projected to the FDC signifies the observed streamflow value representing change within the CSS (equation 3).

$$
\operatorname{Mid} P o E_{j}=\left[\left(P o E_{j}+P o E_{j+1}\right) / 2\right]
$$

In equation $2, j$ varies from 1 to $n$ with $n$ denoting the number of CSSs.

$$
\operatorname{Mid} Q_{j}=F D C\left[\text { mid } P_{o E}\right]
$$

In equation 3, Mid $Q_{j}$ is streamflow change point and FDC [ ] is the function representing the FDC. Slope of semi logarithmic FDC between two change points is computed using equation (4) where $k$ varies from 1 to $(n-1) . S_{k}$ is the FDC change point gradient.

$$
S_{k}=\left\{A b s\left[\log _{10}\left(Q_{k+1}\right)-\log _{10}\left(Q_{k}\right)\right]\right\} /\left(P o E_{k+1}-\right.
$$

The PoE FDC and OM FDC and the slope curves for monthly and daily data are presented in Figure 3 and Figure 4, respectively. Gradients of both duration curves clearly show the behaviour of high, intermediate and low flow segments. With the increase of PoE, the high flow segment displays a marked reduction of slope, indicating the approach to a relatively stable section. In a similar manner, the low flow section indicates a clear deviation from the stable section. Boundary between the segments of respective slope curves are marked to show corresponding segments and they are shown by Figure 3 and Figure 4 . These boundary points show the transition gradient from one flow type to the other. As indicated by dotted arrow in Figure 3 and Figure 4, each transition point has been computed by using the values of two FDC change points. These change points belong to two streamflow types. Selection of the streamflow threshold from one of these two points does not pose a difficulty because, the high flow threshold has to incline towards the high flow region while the low flow threshold should incline towards the low flow region. Therefore, the projection of transition gradient to the change point of FDC clearly identifies the threshold streamflow which transfers the PoE values either from high flows to intermediate flows or from intermediate flows to low flows.

\subsection{Verification}

Monthly and daily datasets of Tawalama watershed spanning over 8 and 15 years were used to verify the method. Streamflow of Gin Ganga watershed at Tawalama $\left(317 \mathrm{~km}^{2}\right)$ for the water years from 2000/01-2014/15 were available. Average annual streamflow during the period was $2780 \mathrm{~mm} /$ year. The PoE and OM FDC together with change point gradient graphs for monthly (Figure 5) and daily (Figure 6) temporal resolutions demonstrate the high, intermediate and low flow segments and associated streamflow thresholds computed using the proposed method.

Single plots of FDC, streamflow hydrographs and corresponding thresholds for both watersheds at monthly and daily temporal resolutions are shown in Figure 7-Figure 12. These plots, which are constructed in a manner similar to those of Vogel and Fennessey [53], demonstrate the behaviour of streamflow thresholds with respect to observed streamflow. Plotting streamflow hydrographs in the background highlighting the median curve reinforces that the thresholds determined by the OM FDC and the average slope of CSS of FDC are compatible with the behaviour of watershed over each temporal scale.

\section{Results}

Summary results of the streamflow threshold computations for Kalu and Gin Gangas with different data lengths and at two temporal resolutions are shown in Table 1. 


\subsection{Ellagawa Watershed}

Results of Ellagawa watershed indicated that when monthly data are used, the high flow threshold PoE is $17 \%$ with a corresponding streamflow magnitude of $7.07 \mathrm{~mm} /$ day, while the low flow threshold PoE is $68 \%$ with a corresponding streamflow of $2.03 \mathrm{~mm} /$ day.

Daily streamflow thresholds computed for Ellagawa watershed revealed that the high and low streamflow threshold PoE values are 10\% and $76 \%$ while corresponding streamflow magnitudes are 9.06 and $1.25 \mathrm{~mm} /$ day, respectively. Both PoE thresholds and streamflow magnitudes of daily and monthly evaluations displayed a clear difference in the threshold values.

\subsection{Tawalama Watershed}

In the case of Tawalama watershed, the high flow threshold for monthly data remained the same irrespective of the length of dataset used for the construction of PoR FDC. In this watershed at monthly temporal resolution, the high flow threshold PoE is $31 \%$ with a corresponding streamflow magnitude of $8.92 \mathrm{~mm} /$ day. The low flow threshold PoE of the watershed for monthly scale is $72 \%$ with a corresponding streamflow magnitude of $5.01 \mathrm{~mm} /$ day.

The respective high and low streamflow PoE thresholds for 8 -year daily dataset are $22 \%$ and $76 \%$ with corresponding streamflow magnitudes as 9.78 and $3.29 \mathrm{~mm} /$ day, respectively. The high and low streamflow threshold PoE values for the 15-year daily dataset are $27 \%$ and $79 \%$ respectively with corresponding streamflow magnitudes as $8.45 \mathrm{~mm} /$ day and $3.09 \mathrm{~mm} /$ day. These streamflow thresholds are Gin Ganga and Kalu Ganga watershed signatures for each temporal resolution.

\section{Discussion}

A PoR FDC requires a long dataset to support long term planning. The equal monthly threshold values of Tawalama watershed for both 8 and 15-year datasets express the possibility of using an 8-year dataset for a monthly analysis. On the other hand, an increase of data length from 8 to 15 years in Tawalama watershed significantly increased the PoE thresholds. This shows that sufficiently long datasets must be chosen when streamflow thresholds are computed. Threshold PoE values of the two temporal resolutions demonstrate values of the same order of magnitude but the corresponding streamflow magnitudes show comparatively high variations because of the averaging effect of monthly data. Therefore, it is necessary to select the appropriate temporal resolution for a particular application and then determine the corresponding streamflow thresholds.

Considering the length of data used for the computations, the watershed signatures for Ellagawa watershed are given by the 8-year dataset. In case of the Tawalama watershed, the best thresholds are given by the 15-year dataset. The two watersheds selected for the present study are situated closer to each other in the same climatic zone of Sri Lanka. However, the threshold PoE values for both high and low flows indicated a marked difference reflecting the differences in the characteristics of watershed streamflow. This shows that, for rational watershed management, it is important to capture the watershed-signature streamflow thresholds instead of using generalized norms.

The complementary characteristics of OM FDC and the average slope of CSS in FDC curve introduced in this work are fundamental to the determination of streamflow thresholds corresponding to the high, intermediate and low streamflow. Conjunctive or harmonious nature of using OM FDC and change point gradient of FDC to identify CSS bounding the intermediate-flow region of FDC to determine the PoE thresholds is the specialty of rationalization in the present work. PoE threshold values of streamflow classes identified for each watershed enable a watershed manager to evaluate hydrologic models with respect to the desired objectives.

In both watersheds, low flow thresholds with daily data indicated higher PoE values for each watershed when compared with those determined using monthly data. On the contrary, the high flow threshold PoE values with daily data in both watersheds are lower than those with monthly data. Therefore, hydrologists who are targeting model calibration and verification to suit a particular water management objective should identify appropriate streamflow thresholds to ensure better model performance. 


\section{Conclusions}

- Using two watersheds, two temporal resolutions and two different data lengths, this paper successfully presents a new technique which utilizes the shape of flow duration curve to capture the streamflow thresholds for a given watershed.

- The conceptualization based on the order of magnitude of flow duration curve and the average slope of consistent flow regimes, enable the identification of specific and plausible PoE thresholds which are watershed signatures.

- The present study which confirms that the watershed specific PoE values corresponding to streamflow thresholds depend on the temporal resolution, cautions the use of traditional methods based on generalized thresholds.

- In both watersheds, low flow thresholds with daily data indicated higher PoE values when compared with those determined using monthly data. The high flow threshold PoE values with daily data in both watersheds are lower than those with monthly data. This behaviour due to the averaging of monthly data should be recognized by the watershed managers when they use streamflow thresholds to plan water resources management projects.

- The present method, while significantly contributing to the rational evaluation of hydrologic models for each major flow type, enhances the confidence of engineers when using design safety factors for streamflow management in case of high, intermediate or lowflow regions.

Table 1 - Streamflow Threshold Results of Gin Ganga and Kalu Ganga Watersheds

\begin{tabular}{|c|c|c|c|c|c|c|c|}
\hline \multirow{2}{*}{$\begin{array}{l}\text { Temporal } \\
\text { Resolution }\end{array}$} & \multirow{2}{*}{$\begin{array}{l}\text { Data } \\
\text { Length in } \\
\text { Water } \\
\text { Years }\end{array}$} & \multirow{2}{*}{$\begin{array}{l}\text { River Basin and } \\
\text { Watershed }\end{array}$} & \multicolumn{2}{|c|}{ High Flow Threshold } & \multicolumn{2}{|c|}{ Low Flow Threshold } & \multirow{2}{*}{ Data Period } \\
\hline & & & PoE & $\begin{array}{l}\text { Streamflow } \\
\text { (mm/day) }\end{array}$ & PoE & $\begin{array}{l}\text { Streamflow } \\
\text { (mm/day) }\end{array}$ & \\
\hline \multirow{3}{*}{ Monthly } & \multirow{2}{*}{8} & $\begin{array}{l}\text { Kalu Ganga at } \\
\text { Ellagawa }\end{array}$ & $17 \%$ & 7.07 & $68 \%$ & 2.03 & $\begin{array}{l}2006 / 2007- \\
2013 / 2014\end{array}$ \\
\hline & & \multirow{2}{*}{$\begin{array}{l}\text { Gin Ganga at } \\
\text { Tawalama }\end{array}$} & $31 \%$ & 8.92 & $72 \%$ & 5.01 & $\begin{array}{l}2000 / 2001- \\
2008 / 2009\end{array}$ \\
\hline & 15 & & $31 \%$ & 8.92 & $72 \%$ & 5.01 & $\begin{array}{l}2000 / 2001- \\
2014 / 2015\end{array}$ \\
\hline \multirow{3}{*}{ Daily } & \multirow{2}{*}{8} & $\begin{array}{l}\text { Kalu Ganga at } \\
\text { Ellagawa }\end{array}$ & $10 \%$ & 9.06 & $76 \%$ & 1.25 & $\begin{array}{l}2006 / 2007- \\
2013 / 2014\end{array}$ \\
\hline & & \multirow{2}{*}{$\begin{array}{l}\text { Gin Ganga at } \\
\text { Tawalama }\end{array}$} & $22 \%$ & 9.78 & $76 \%$ & 3.29 & $\begin{array}{l}2000 / 2001- \\
2008 / 2009\end{array}$ \\
\hline & 15 & & $27 \%$ & 8.45 & $79 \%$ & 3.09 & $\begin{array}{l}2000-2001- \\
2014 / 2015\end{array}$ \\
\hline
\end{tabular}




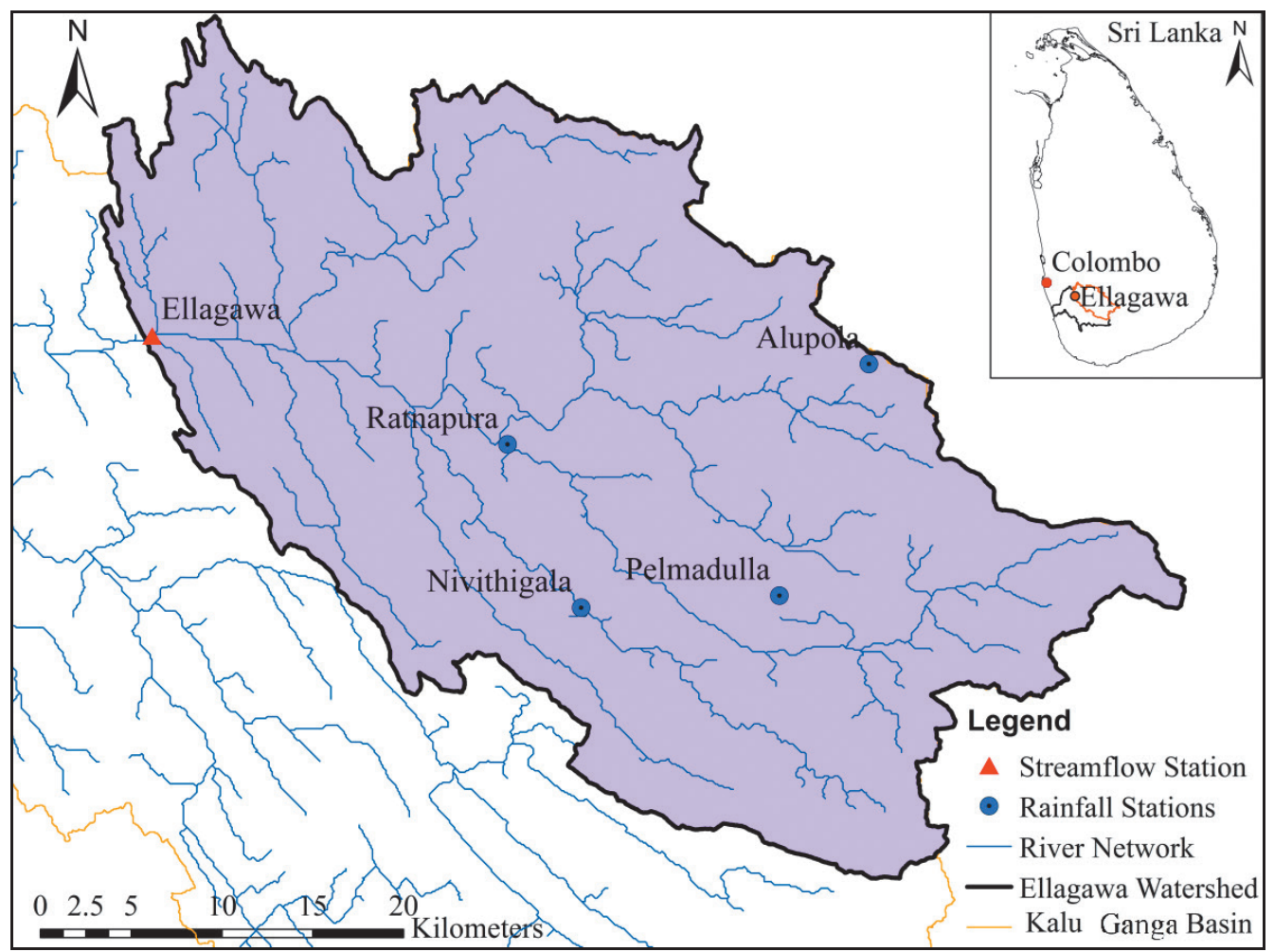

Figure 1 - Kalu Ganga Watershed at Ellagawa

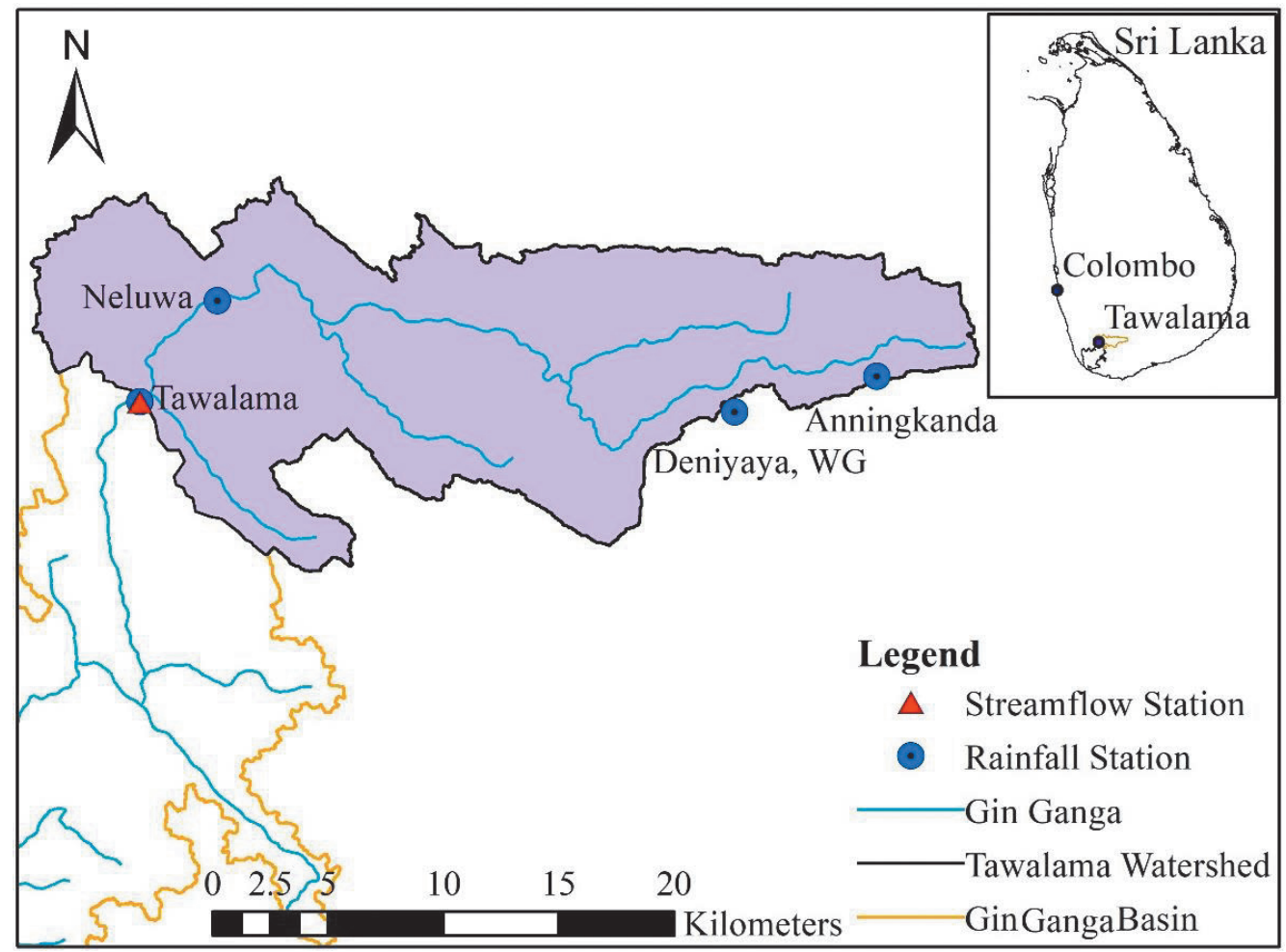

Figure 2 - Gin Ganga Watershed at Tawalama 
Kalu Ganga Monthly Streamflow 2006/2007-2013/2014
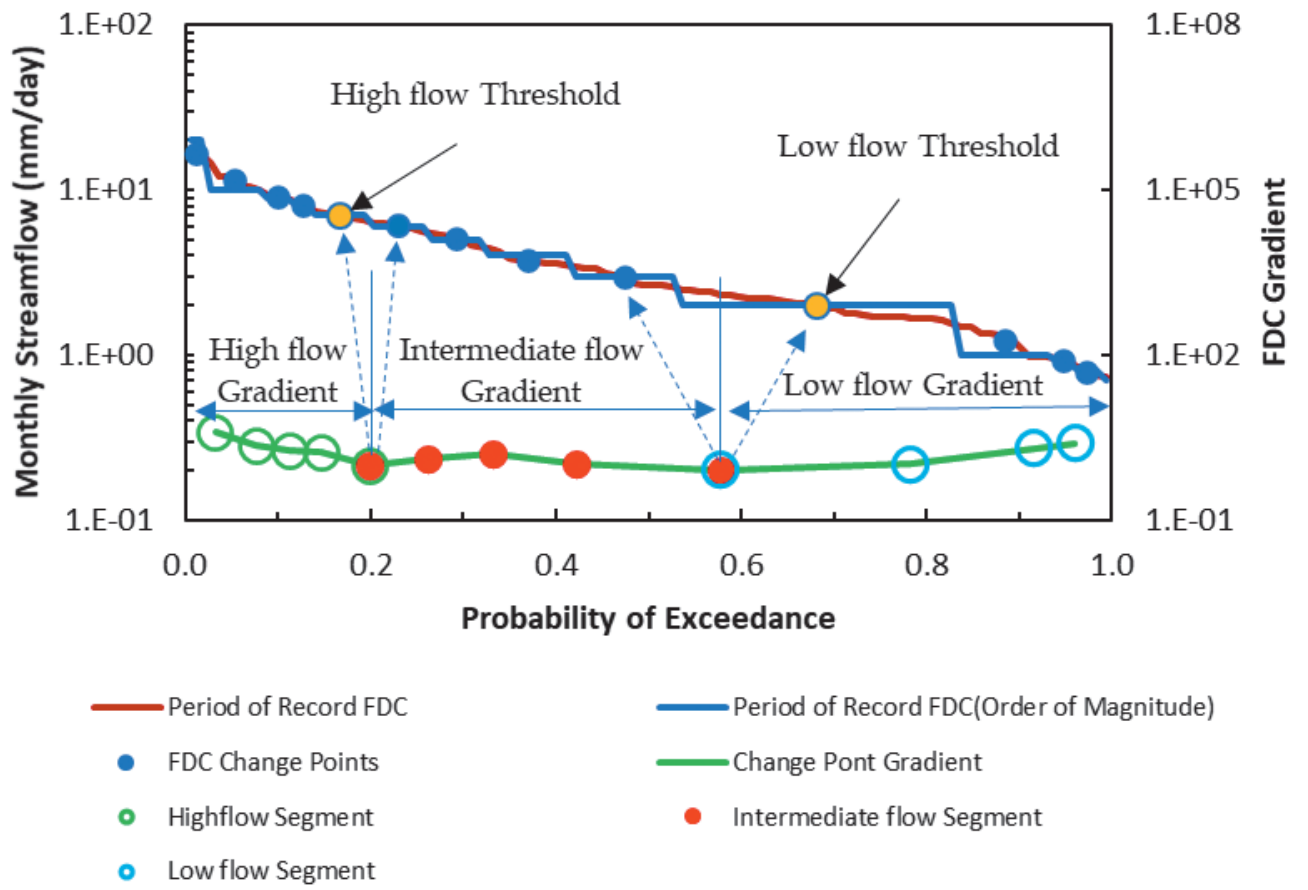

Figure 3 - Monthly FDCs and FDC Gradients of Kalu Ganga (8-Water Year Data)

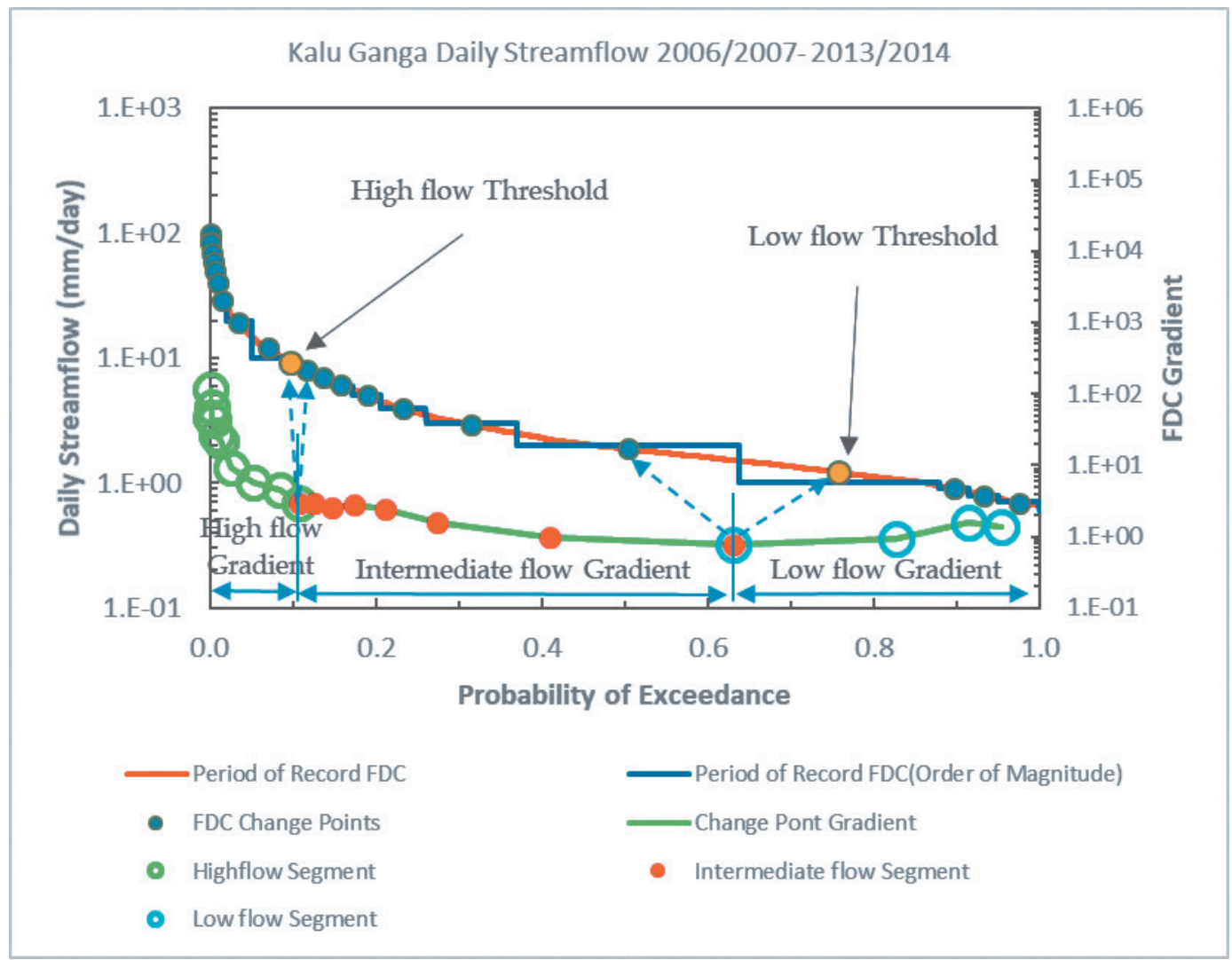

Figure 4 - Daily FDCs and FDC Gradients Kalu Ganga (8-Water Year Data) 


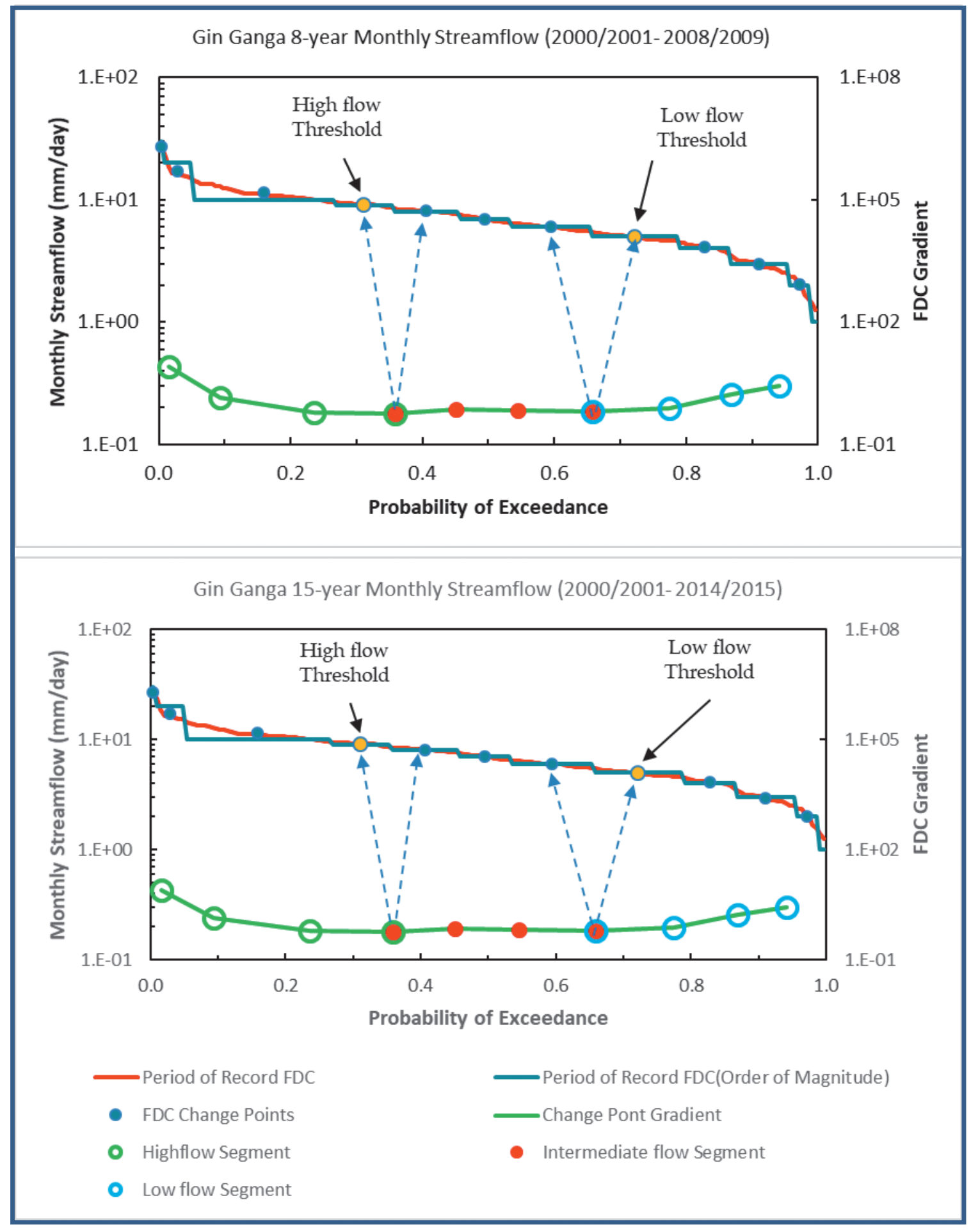

Figure 5 - Monthly FDCs and FDC Gradients of Gin Ganga (8 year \& 15-year datasets, top and bottom respectively) 


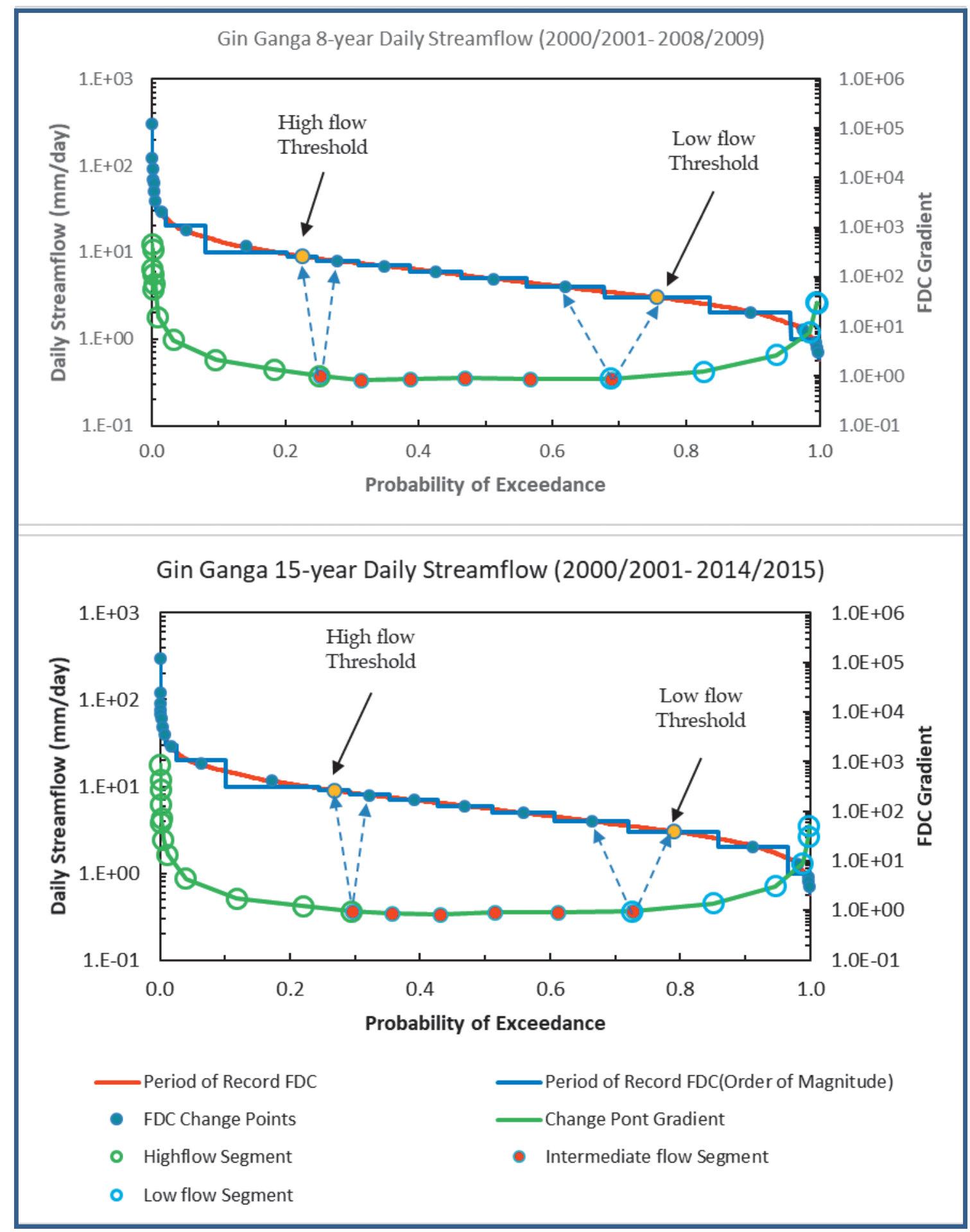

Figure 6 - Daily FDCs and FDC Gradients of Gin Ganga (8 year \& 15-year datasets top and bottom respectively) 


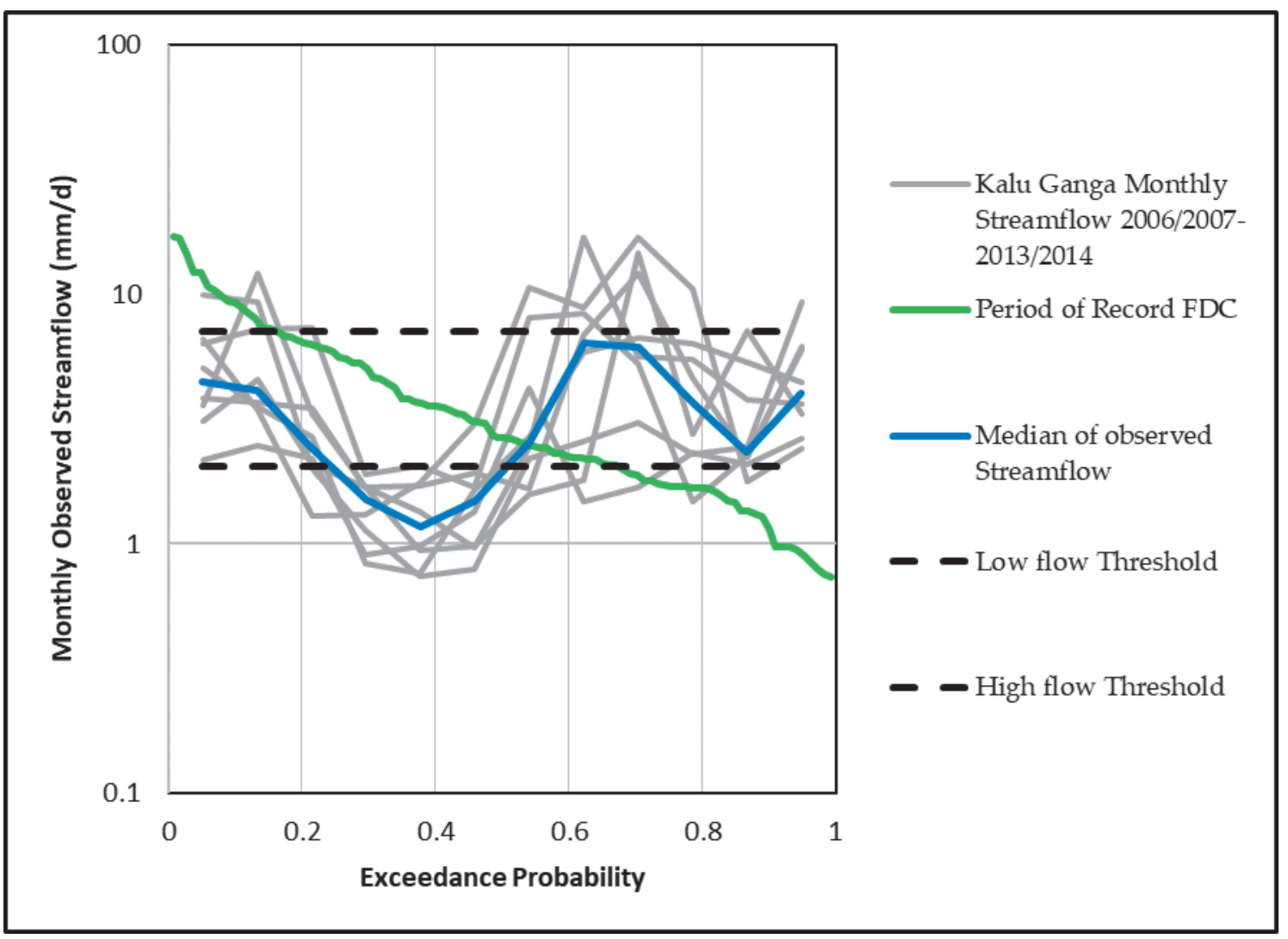

Figure 7 - Kalu Ganga Streamflow Thresholds (Monthly Data- 8 Water Year Data)

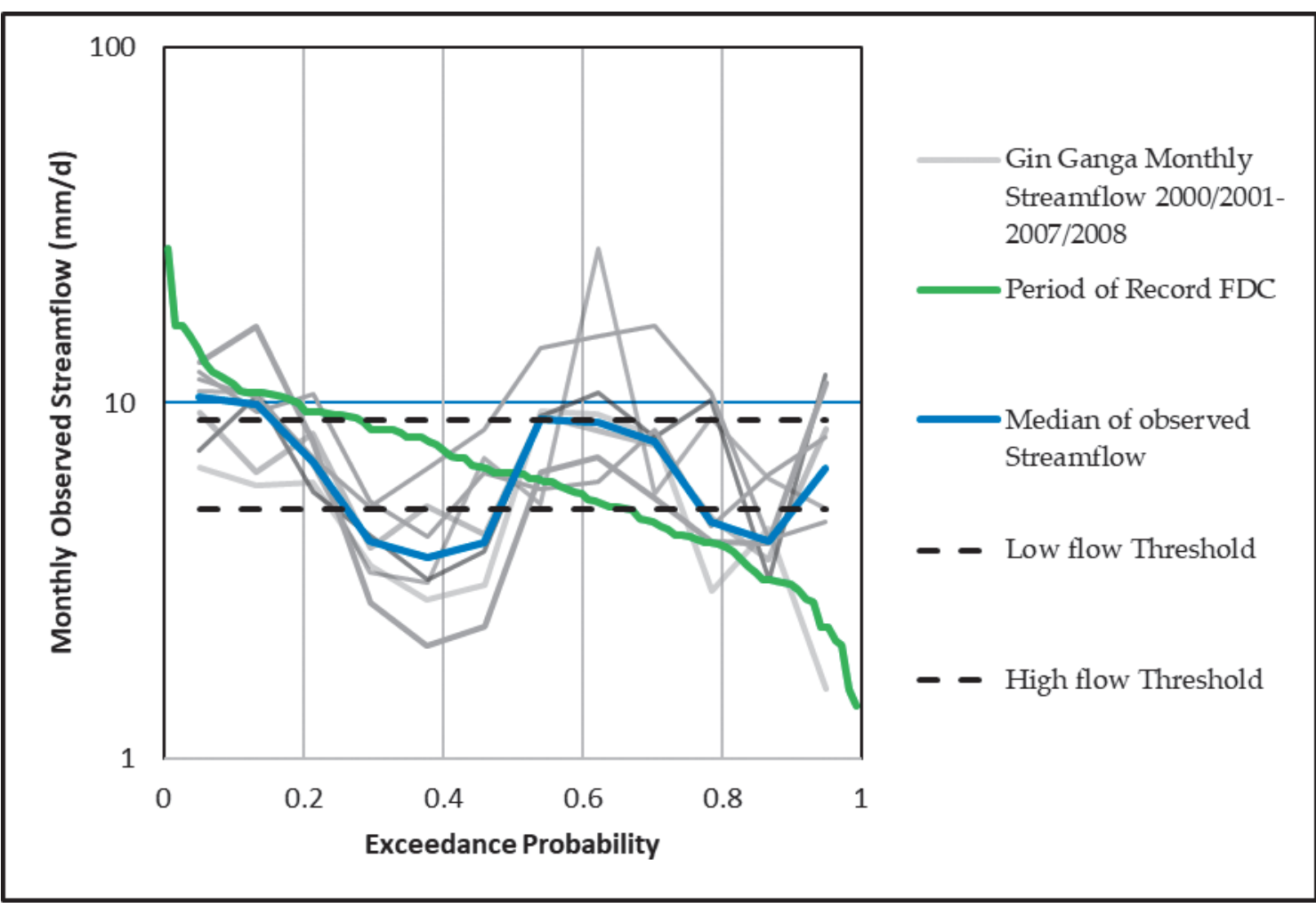

Figure 8 - Gin Ganga Streamflow Thresholds (Monthly Data - 8 Water Year Data) 


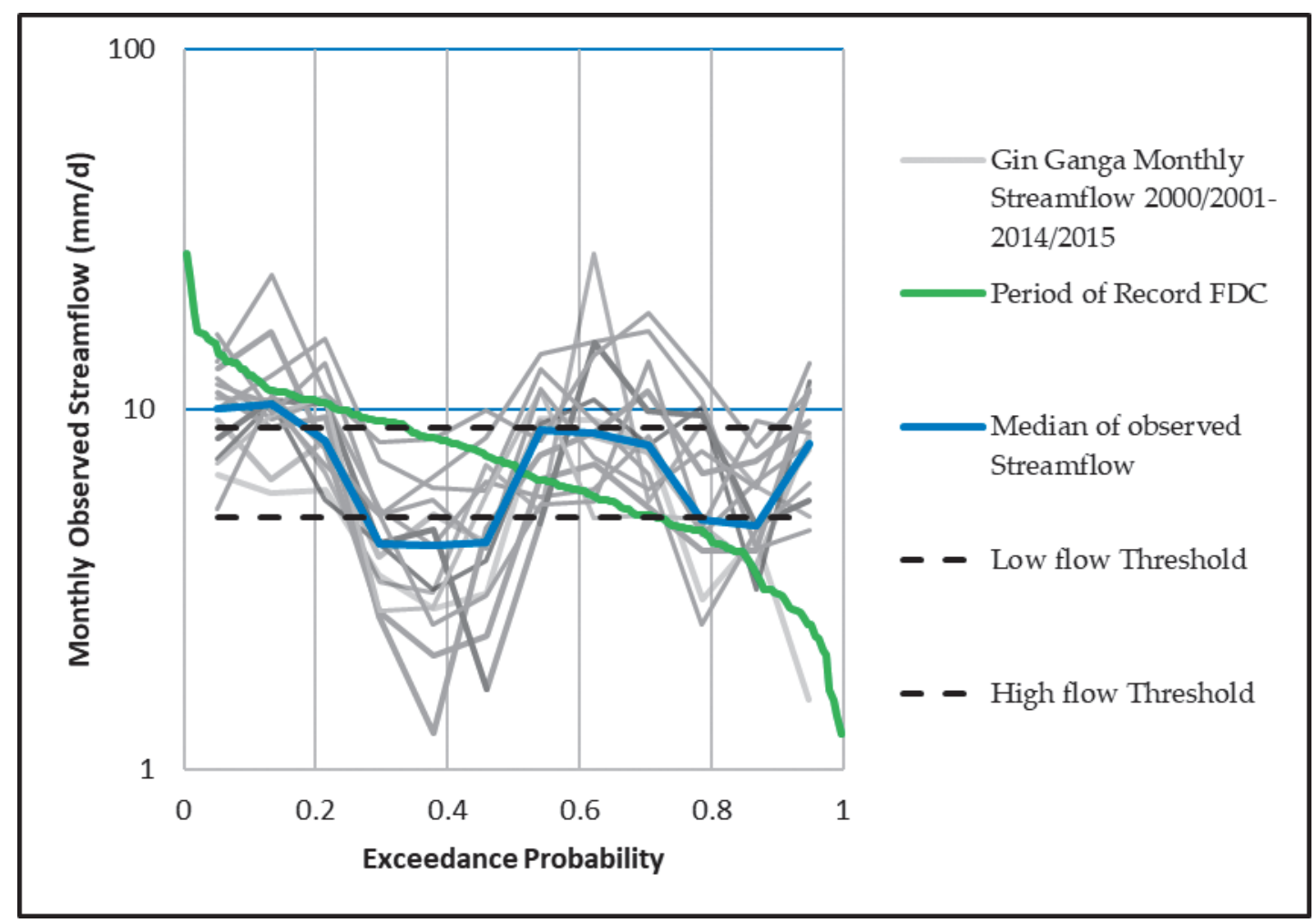

Figure 9 - Gin Ganga Streamflow Thresholds (Monthly Data - 15 Water Years)

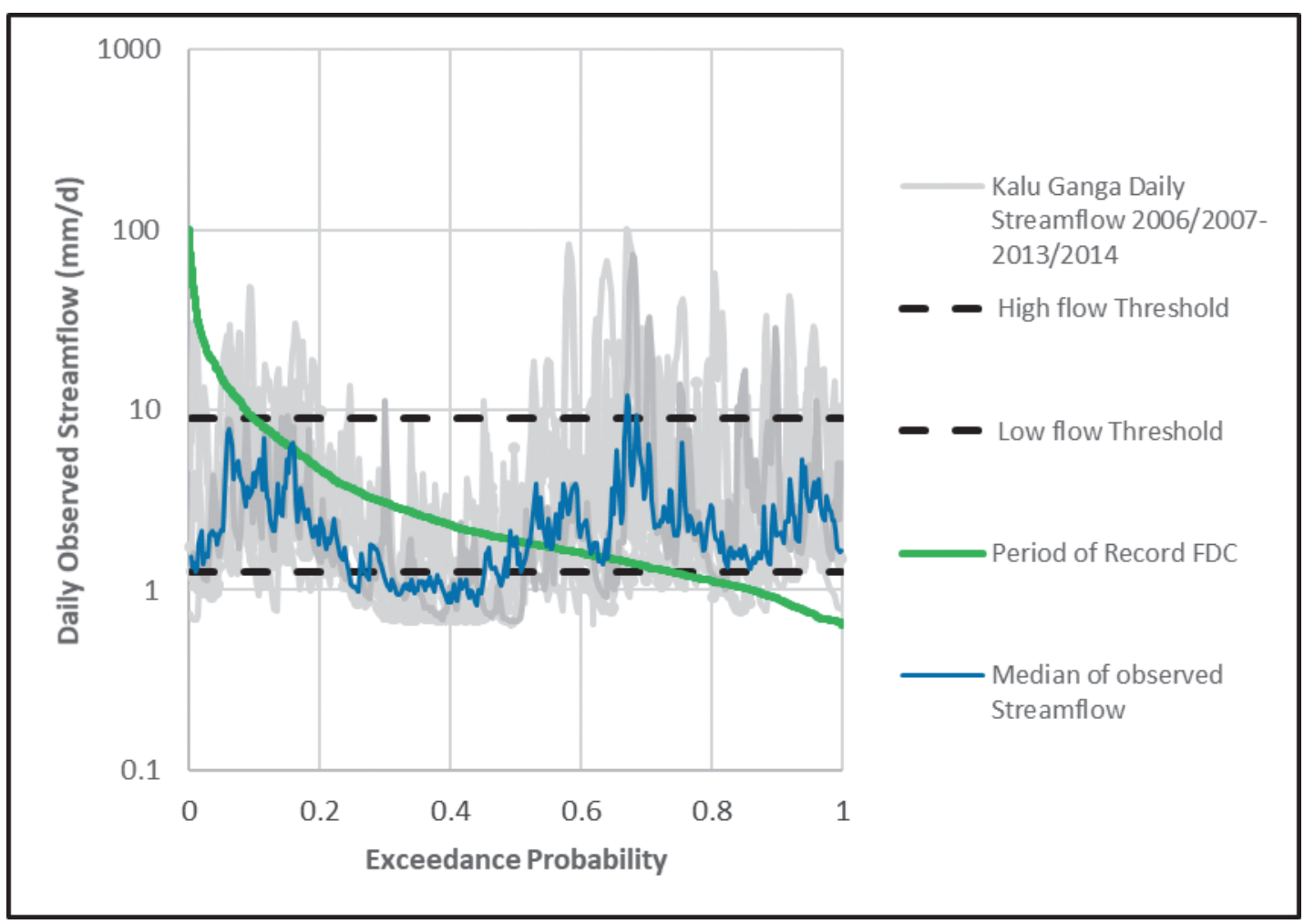

Figure 10 - Kalu Ganga Streamflow Thresholds (Daily Data- 8 Water Years) 


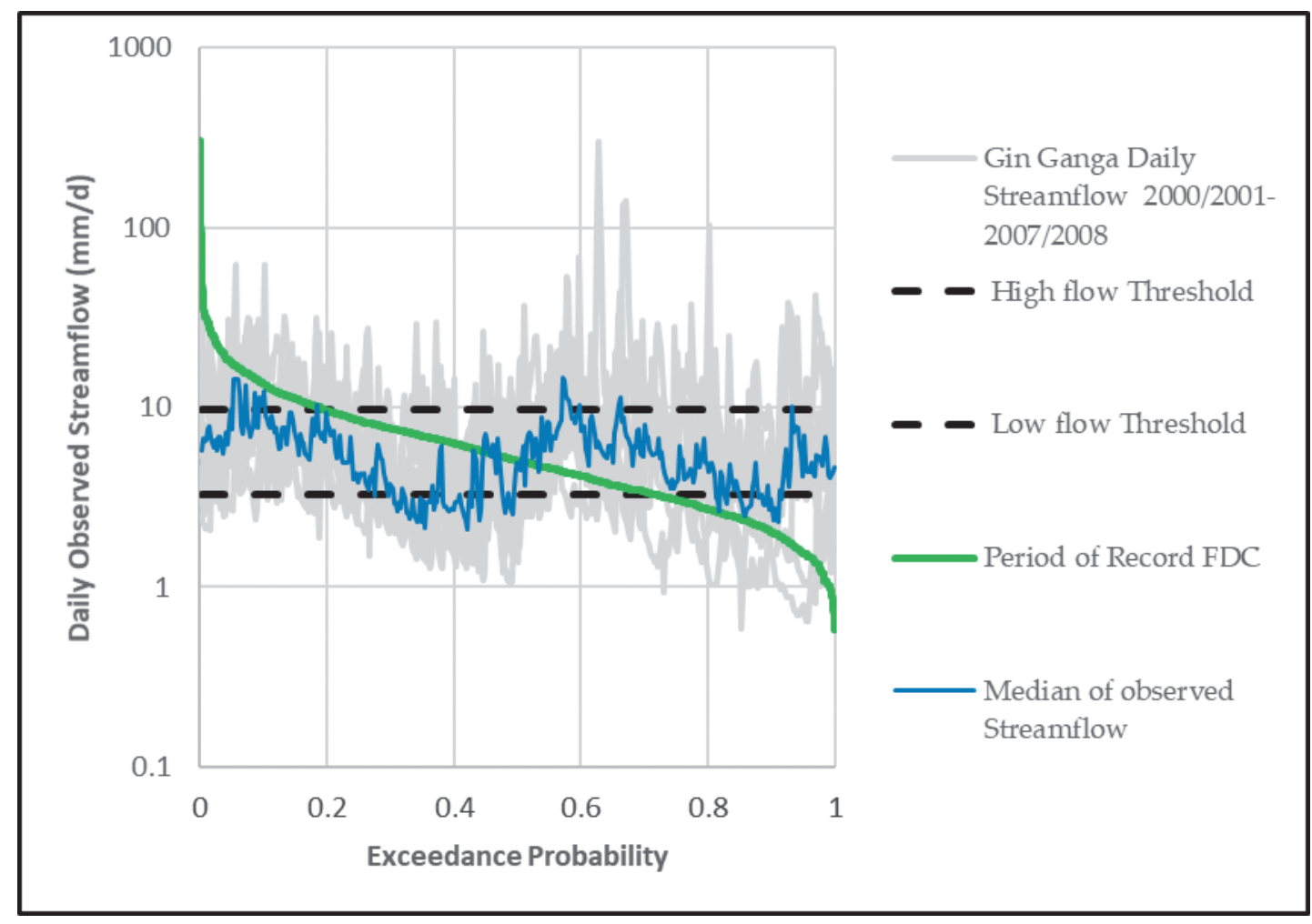

Figure 11 - Gin Ganga Streamflow Thresholds (Daily Data - 8 Water Years)

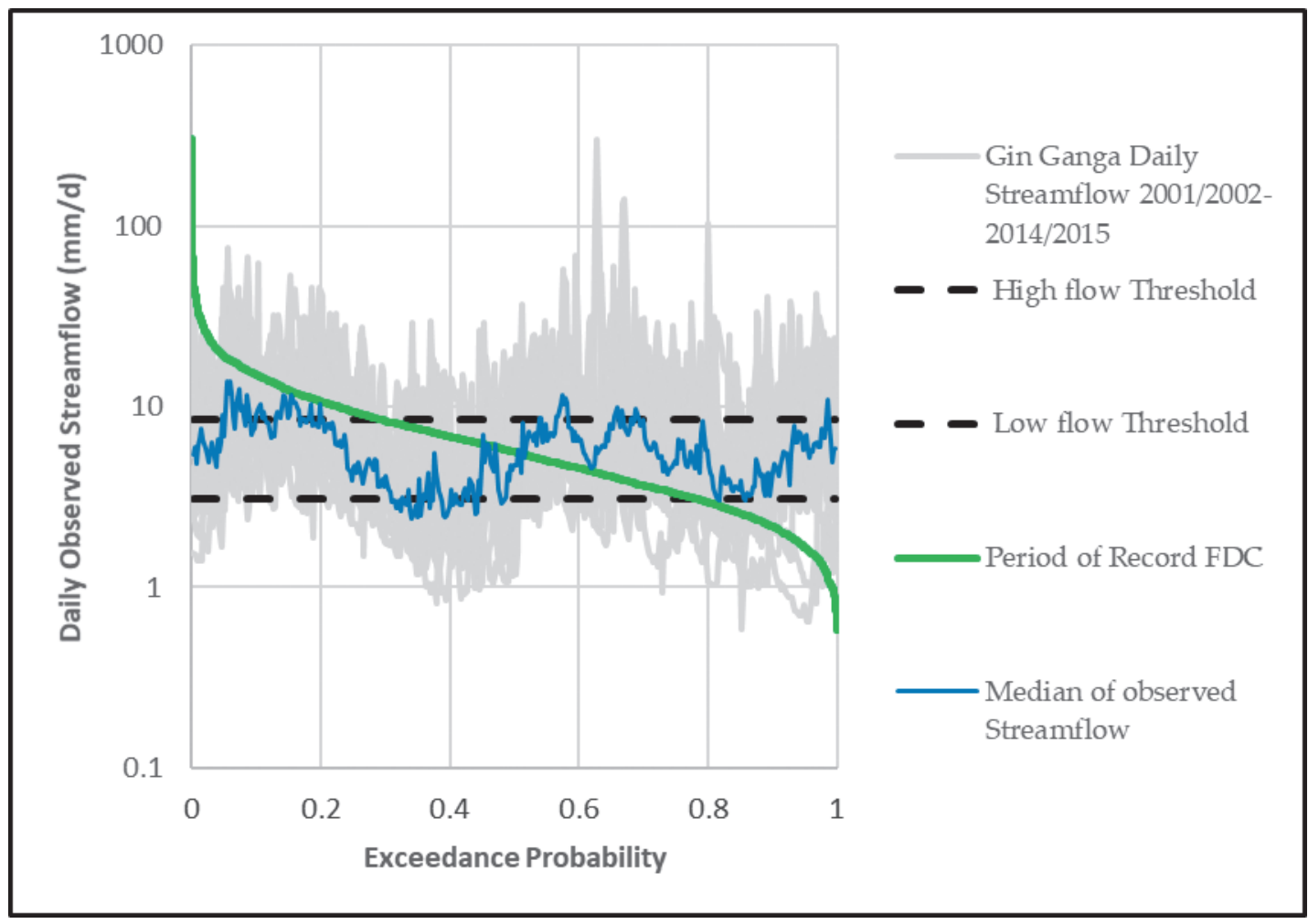

Figure 12 - Gin Ganga Streamflow Thresholds (Daily Data - 15 Water Years) 


\section{References}

1. Ward, P. J., Kongman, B., Salamon, P., Simpson, A., Bates, P., T. De Groeve., Muis, S., de Perez, E.C., Rudari, R., Trigg, M. A., and Winsemius, H.C., "Usefulness and Limitations of Global Flood Risk Models," Nat. Clim. Chang., vol. 5, no. 8, pp. 712-715, 2015.

2. Leskens, J. G., Brugnach, M., Hoekstra, A. Y., and Schuurmans, W., "Why are Decisions in Flood Disaster Management So Poorly Supported by Information from Flood Models?," Environ. Model. Softw., vol. 53, pp. 53-61, Mar. 2014.

3. Vaze, J., Jordan, P., Beecham, R., Frost, A., and Summerell, G., Guidelines for Rainfall-Runoff Modelling: Towards best Practice Model Application, Version 1., no. December. University Drive South Bruce, ACT, 2617: eWater Cooperative Research Centre, 2011.

4. Zhang, C., Wang, R., and Meng, Q., "Calibration of Conceptual Rainfall-Runoff Models Using Global Optimization," Adv. Meteorol., vol. 2015, pp. 1-12, Mar. 2015.

5. Hughes, D. A., and Metzler, W., “Assessment of Three Monthly Rainfall-Runoff Models for Estimating the Water Resource Yield of Semiarid Catchments in Namibia," Hydrol. Sci. J., vol. 43, no. March 2015, pp. 283-297, 1998.

6. Boughton, W., "Catchment Water Balance Modelling in Australia 1960-2004," Agric. Water Manag., vol. 71, no. 2, pp. 91-116, 2005.

7. Jiang, T., David, Y., Xu, C., Chen, X., Chen, X., and Singh, V. P., "Comparison of Hydrological Impacts of Climate Change Simulated by Six Hydrological Models in the Dongjiang Basin, South China," J. Hydrol., vol. 336, pp. 316-333, 2007.

8. Hanington, P., Toan, T. Q., Tri, D. V. P., Vu, N. A., Doan, and Kiem, A. S., "A Hydrological Model for Interprovincial Water Resource Planning and Management: A Case Study in the Long Xuyen Quadrangle, Mekong Delta, Vietnam," J. Hydrol., vol. 547, pp. 1-9, Apr. 2017.

9. Lüke, A., and Hack, J., "Comparing the Applicability of Commonly Used Hydrological Ecosystem Services Models for Integrated Decision-Support," 2018.

10. Sun, Y. W., Li, Q. Y., Liu, L., Xu, C. D., and Liu, Z. P., "Hydrological Simulation Approaches for BMPs and LID Practices in Highly Urbanized Area and Development of Hydrological Performance Indicator System," Water Sci. Eng., vol. 7, no. 2, pp. 143-154, 2014.

11. Fowler, K., Peel, M., Western, A., and Zhang, L., Improved Rainfall - Runoff Calibration for
Drying Climate: Choice of Objective Function," Water Resour. Res., vol. 54, no. 5, pp. 3392-3408, 2018.

12. Yilmaz, K. K., Gupta, H. V., and Wagener, T., “A Process-Based Diagnostic Approach to Model Evaluation: Application to the NWS Distributed Hydrologic Model," Water Resour. Res., vol. 44, no. 9 , Sep. 2008.

13. Hansen, C., Shiva, J. S., Mcdonald, S., and Abors, A., "Assessing Retrospective National Water Model Streamflow with Respect to Droughts and Low Flows in the Colorado River Basin," J. Am. Water Resour. Assoc., pp. 1-12, 2019.

14. Chau, K. W., Wu, C. L., and Li, Y. S., "Comparison of Several Flood Forecasting Models in Yangtze River," J. Hydrol. Eng. ASCE, vol. 10, no. 6, pp. 485-491, 2005.

15. Wang, Q. J., Pagano, T. C., Zhou, S. L., Hapuarachchi, H. A. P., Zhang, L., and Robertson, D. E., "Monthly Versus Daily Water Balance Models in Simulating Monthly Runoff," J. Hydrol., vol. 404, no. 3-4, pp. 166-175, 2011.

16. Dessai, S., and Sluijs, J. V. D., Uncertainty and Climate Change Adaptation - a Scoping Study, NWSE-2007., no. 2007-198. Utrecht The Netherlands: Copernicus Institute for Sustainable Development and Innovation, Department of Science Technology and Society, 2007.

17. George, B., Malano, H. M., and Davidson, B., "Integrated Water Allocation-Economic Modelling at a Catchment Scale," in MODSIM 2007, Christchurch, 2007, pp. 322-329.

18. Vigiak, O., Lutz, S., Mentzafou, A., Chiogna, G., Tuo, Y., Majone, B., Beck, H., de Roo, A., Malago, A., Bouraoui, F., Kumar, R., Samaniego, L., Merz, R., Gamvroudis, C., Skoulikidis, N., Bellin, A., Acuna, V., Mori, N., Ludwig, R., and Pistocchi, A., "Uncertainty of Modelled Flow Regime for Flow-Ecological Assessment in Southern Europe," Sci. Total Environ., vol. 615, pp. 10281047,2018

19. Mohamoud, Y. M., "Prediction of Daily Flow Duration Curves and Streamflow for Ungauged Catchments using Regional Flow Duration Curves," Hydrol. Sci. J., vol. 53, no. 4, pp. 706-724, 2008.

20. Dang, Q. T., Laux, P., and Kunstmann, H., "Future High- and Low-Flow Estimations for Central Vietnam: A Hydro-Meteorological Modelling Chain Approach," Hydrol. Sci. J., vol. 62, no. 11, pp. 1867-1889, 2017.

21. Ali, K., Bajracharyar, R. M., and Raut, N., "Advances and Challenges in Flash Flood Risk Assessment: A Review," J. Geogr. Nat. Disasters, vol. 07, no. 02, 2017. 
22. Döll, P., Jimenez-Cisneros, B., Oki, T., Arnell, N. W., Benito, G., Cogley, J. G., Jiang, T., Kundzewicz, Z. W., Mwakalila, S., and Nishijima, A., "Integrating Risks of Climate Change into Water Management," Hydrol. Sci. J., vol. 60, no. 1, pp. 4-13, Jan. 2015.

23. Poff, N. L., Allan, J. D., Bain, M. B., Karr, J. R., Prestegaard, K. L., Richter, B. D., Sparks R. E., and Stromberg, J. C., "The Natural Flow Regime," Bioscience, vol. 47, no. 11, pp. 769-784, 1997.

24. Oregon State University, "Streamflow Evaluations for Watershed Restoration Planning and Design," An Interactive Guide and Tutorial. pp. 1-15, 2017.

25. USGS, "Monthly and Yearly Streamflow Patterns," The United States Geological Survey. [Online]. Available:

https://www.usgs.gov/special-topic/waterscience-school/science/monthly-and-yearlystreamflow-patterns?qtscience_center_objects $=0 \# q \mathrm{t}-$ science_center_objects. [Accessed: 24-Dec-2019].

26. Moriasi, D. N., Wilson, B. N., Douglas-Mankin, K. R., Arnold, J. G., and Gowda, P. H., "Hydrologic and Water Quality Models: Use, Calibration, and Validation," Am. Soc. Agric. Biol. Eng., vol. 55, no. 4, pp. 1241-1247, 2012.

27. Gupta, H. V., Sorooshian, S., and Yapo, P. O., "Toward Improved Calibration of Hydrologic Models: Multiple and Noncommensurable Measures of Information," Water Resour. Res., vol. 34, no. 4, pp. 751-763, 1998.

28. Post, D. A., "A New Method for Estimating Flow Duration Curves: an Application to the Burdekin River Catchment, North Queensland, Australia," in 2nd International Congress on Environmental Modelling and Software-Osnabrück, Germany, 2004.

29. Smakhtin, V. U., Shilpakar, R. L., and Hughes, D. A., "Hydrology-Based Assessment of Environmental Flows: An Example from Nepal," Hydrol. Sci. J., vol. 51, no. 2, pp. 207-222, 2006.

30. Khandu, D., “A Monthly Water Balance Model for Evaluation of Climate Change Impacts on the Streamflow of Ginganga and Kelani Ganga Basins, Sri lanka," University of Moratuwa, 2015.

31. Sharifi, M. B., "Calibration and Verfication of a Two Parameter Monthly Water Balance Model and its Application Potential for Evaluation of Water Resources - A Case Study of Kalu and Mahaweli Rivers of Sri Lanka," University of Moratuwa, 2015.

32. Dissanayake, P., "Applicability of a Two Parameter Water Balance Model To Simulate Daily Rainfall Runoff - Case Study of Kalu and
Gin River Basins In Sri Lanka," Univerisy of Moratuwa, 2017.

33. Wagener, T., Boyle, D. P., Lees, M. J., Wheater, H. S., Guptha, H. V., and Sorooshian, S., "A Framework for Development and Application of Hydrological Models," Hydrol. Earth Syst. Sci., vol. 5, no. 1, pp. 13-26, 2001.

34. Huang, G. H., and Loucks, D. P., "An Inexact Two-Stage Stochastic Programming Model for Water Resources Management Under Uncertainty," Civ. Eng. Environ. Syst., vol. 17, no. 2, pp. 95-118, 2000.

35. Ranatunga, T., Tong, Susanna, T. Y., and Yang, Jeffrey, Y., "An Approach to Measure Parameter Sensitivity in Watershed Hydrologic Modeling," Hydrol. Sci. J., vol. 62(1), pp. 76-92, 2016.

36. Laaha, G., and Blöschl, G., "A National Low Flow Estimation Procedure for Austria," Hydrol. Sci. J., vol. 52, no. 4, pp. 625-644, 2007.

37. Gustard, A., Bullock, A., and Dixon, J. M., "Low Flow Estimation in the United Kingdom: Institute of Hydrology - Report No. 108," 1992.

38. EPA, “An Approach for Using Load Duration Curves in the Development of TMDLs An Approach for Using Load Duration Curves in the Development of TMDLs," Environmental Protection Agency, Watershed Branch (4503T), Office of Wetlands, Oceans and Watersheds, Washington, DC 20460, 2007.

39. Sugiyama, H., Vudhivanich, V., Whitaker, A.C., and Lorsirirat, K., "Stochastic Flow Duration Curves for Evaluation of Flow Regimes in Rivers," J. Am. Water Resour. Assoc., vol. 39, no. 1, pp. 47-58, Feb. 2003.

40. Risley, J., Stonewall, A., and Haluska, T., "Estimating Flow-duration and Low-Flow Frequency Statistics for Unregulated Streams in Oregon: USGS Scientific Investigations Report 2008-5126," 2008.

41. Searcy, J. K., "Flow-Duration Curves," in Manual of Hydrology: Part 2. Low-Flow Techniques, USGS WSP 1., Washington DC: US Government Printing Office, 1959, p. 33.

42. Li, L. J., Zhang, L., Wang, H., Wang, J., Yang, J., Jiang, D., Li, J., and Qin, D., "Assessing the Impact of Climate Variability and Human Activities on Streamflow from the Wuding River Basin in China," Hydrol. Process., vol. 21, no. 25, pp. 3485-3491, Dec. 2007.

43. Sung, J. H., and Chung, E. S., “Development of Streamflow Drought Severity-durationFrequency Curves using the Threshold Level Method," Hydrol. Earth Syst. Sci., vol. 18, no. 9, pp. 3341-3351, Sep. 2014. 
44. Kjeldsen, T. R., Lundorf, A., and Rosbjerg, D., "Use of a Two-Component Exponential Distribution in Partial duration Modelling of Hydrological Droughts in Zimbabwean Rivers," Hydrol. Sci. J., vol. 45, no. 2, pp. 285-298, Apr. 2000.

45. Eslamian, S., Ed., Engineering Hydrology. 6000 Broken Sound Parkway NW, Suite 300 Boca Raton, FL 33487-2742: CRC Press Taylor \& Francis Group, 2014.

46. Jayadeera, P., "Development of a Rainfall Runoff Model for Kalu Ganga Basin of Sri Lanka using HEC-HMS Model," University of Moratuwa, 2016.

47. Jha, R., Sharma, K. D., and Singh, V. P., “Critical Appraisal of Methods for the Assessment of Environmental Flows and their Application in Two River Systems of India," KSCE J. Civ. Eng., vol. 12, no. 3, pp. 213-219, 2008.

48. Mckay, S. K., and Fischenich, J. C., “Development and Application of Flow Duration Curves for Stream Restoration, EBA Technical Notes Collection. ERDC TN-EMRRP-SR-49," Athens, GA, 2016

49. DHV Consultants BV and Delft Hydraulics with Halcrow, "How to Analyse Discharge Data Main Text: Section 3," New Delhi, 1999.

50. Verma, R. K., Murthy, S., Verma, S., and Mishra, S. K., "Design Flow Duration Curves for Environmental Flows Estimation in Damodar River Basin, India," Appl. Water Sci., vol. 7, no. 3, pp. 1283-1293, Jun. 2017.

51. Vogel, R. M. and Fennessey, N. M., "Flow Duration Curves II : A Review of Applications in Water Resources Planning," Water Resour. Bull., vol. 31, no. 6, pp. 1029-1039, 1995.

52. Pool, S., Viviroli, D., and Seibert, J., "Prediction of Hydrographs and Flow-duration Curves in Almost Ungauged Catchments: Which Runoff Measurements are Most Informative for Model Calibration?," J. Hydrol., vol. 554, pp. 613-622, Nov. 2017.

53. Vogel, R. M., and Fennessey, N. M., "FlowDuration Curves I: New Interpretation and Confidence Intervals," J. Water Resour. Plan. Manag., vol. 120, no. 4, pp. 485-504, 1994.

54. Huang, S., Kumar, R., Flokrke, M., Yang, T., Hundecha, Y., Kraft, P., Gao, C., Gelfan, A., Liersch, S., Lobanova, A., Strauch, M., van Ogtrop, F., Reinhardt, J., Haberlandt, U., Krysanova, V., "Evaluation of an Ensemble of Regional Hydrological Models in 12 Large-Scale River Basins Worldwide," Clim. Change, vol. 141, no. 3, pp. 399-400, 2017.
55. Mimikou, M., and Kaemaki, S., "Regionalization of Flow Duration Characteristics," J. Hydrol., vol. 82, no. 1-2, pp. 77-91, Nov. 1985.

56. Ponrajah, A. J. P., "Design of Irrigation Headworks for Small Catchments," Department of Irrigation, Colombo Sri Lanka, 1984.

57. Blum, A. G., Archfield, S. A., and Vogel, R. M., "On the Probability Distribution of Daily Streamflow in the United States," Hydrol. Earth Syst. Sci., vol. 21, no. 6, pp. 3093-3103, 2017.

58. Chow, V. T., Maidment, D. R., and Mays, L. W., Applied Hydrology, Int.Ed. McGraw-Hill Singapore, 1988.

59. Cunnane, C., "Unbiassed Plotting Positions - A Review," J. Hydrol., vol. 37, no. 3-4, pp. 205-222, 1978. 